\title{
Mineralization of Natural Spring Water in the City of Daloa (West-Central Côte d'Ivoire)
}

\author{
Eblin Sampah Georges, Konan Kouakou Séraphin, Ohou-Yao Marie-Jeanne Adélaïde, \\ Mangoua Oi Mangoua Jules, Dibi Brou, Kouassi Kouakou Lazare
}

Department of Earth Sciences, Jean Lorougnon Guédé University of Daloa, Cote d'Ivoire

Email:sageblin@gmail.com, konandks@yahoo.fr

How to cite this paper: Georges, E. S., Séraphin, K. K., Adélaïde, O.-Y. M.-J., Jules, M. O. M., Brou, D., \& Lazare, K. K. (2020). Mineralization of Natural Spring Water in the City of Daloa (West-Central Côte d'Ivoire). Journal of Geoscience and Environment Protection, 8, 200-210. https://doi.org/10.4236/gep.2020.812012

Received: November 26, 2020 Accepted: December 21, 2020 Published: December 24, 2020

Copyright $\odot 2020$ by author(s) and Scientific Research Publishing Inc. This work is licensed under the Creative Commons Attribution International License (CC BY 4.0).

http://creativecommons.org/licenses/by/4.0/

(c) (i) Open Access

\begin{abstract}
The water from natural springs in the city of Daloa is increasingly used by the population for its drinking water needs, even though its quality remains unknown. This study aims to determine the acquisition mechanism of the mineralization of these waters. Thus, physicochemical analyses were carried out on 10 spring water samples in February 2019. A summary statistical analysis of the results obtained shows that these waters are acidic $(4.81 \leq \mathrm{pH} \leq 5.39)$ and very weakly mineralised, with $50 \%$ of the conductivities below $100 \mu \mathrm{S} \cdot \mathrm{cm}^{-1}$. The average iron $(0.5 \pm 1.02 \mathrm{mg} / \mathrm{L})$ and manganese $(0.61 \pm 0.90 \mathrm{mg} / \mathrm{L})$ contents show that these two parameters are increasing in the spring water. The Normalized Principal Component Analysis (NPCA) shows that mineralization is mainly controlled by surface inputs of elements (anthropogenic pollution), then the oxidation-reduction phenomenon and, finally, the water-rock contact (mineralization-residence time). Otherwise, the very low expression of water-rock contact (mineralization-residence time) in the acquisition of the mineralization reflects a short residence time of the water in the aquifer.
\end{abstract}

\section{Keywords}

NPCA, Mineralization, Natural Spring, Daloa, Côte d'Ivoire

\section{Introduction}

In recent years, the issue of "drinking water for everybody" has become the subject of major international conferences and is a concern for the whole humanity. Indeed, difficulties of access to good quality water are an international problem that affects most of the world's population, particularly in Africa. In Daloa (Westcentral Côte d'Ivoire), doubts about the quality of the water supplied at the tap and the low coverage rate of the drinking water supply network (Awomon et al., 
2018) are forcing part of the city's population to turn to other sources of supply, particularly water from natural springs and traditional wells. Spring water is increasingly demanded for consumption even though studies on its quality remain very sketchy and even non-existent for some of them (Ligban et al., 2009). However, apart from climatic and anthropogenic factors, the chemical composition of groundwater depends on the characteristics of the surrounding rocks and the reactive substances it may encounter during its infiltration or its emergence (Boubakar, 2011). Therefore, these three factors are determining factors in the identification of the sources of groundwater mineralization (Jain et al., 2005). It is in this context that this study which aims at determining the various processes at the origin of the mineralization of waters from natural springs of the city of Daloa. It is based on Principal Component Analysis (PCA) which is an extremely powerful tool for synthesizing information, used by several authors (Eblin et al., 2014; Chaouki et al., 2015; Soro et al., 2019).

\section{Materials and Methods}

\subsection{Study Area}

The city of Daloa is located in the West-central part of Côte d'Ivoire, between longitudes $6^{\circ} 24^{\prime}$ and $6^{\circ} 29^{\prime}$ West and latitudes $6^{\circ} 50^{\prime}$ and $6^{\circ} 55^{\prime}$ North (Figure 1). It is the capital of the Upper Sassandra region with a population of 319,427 inhabitants

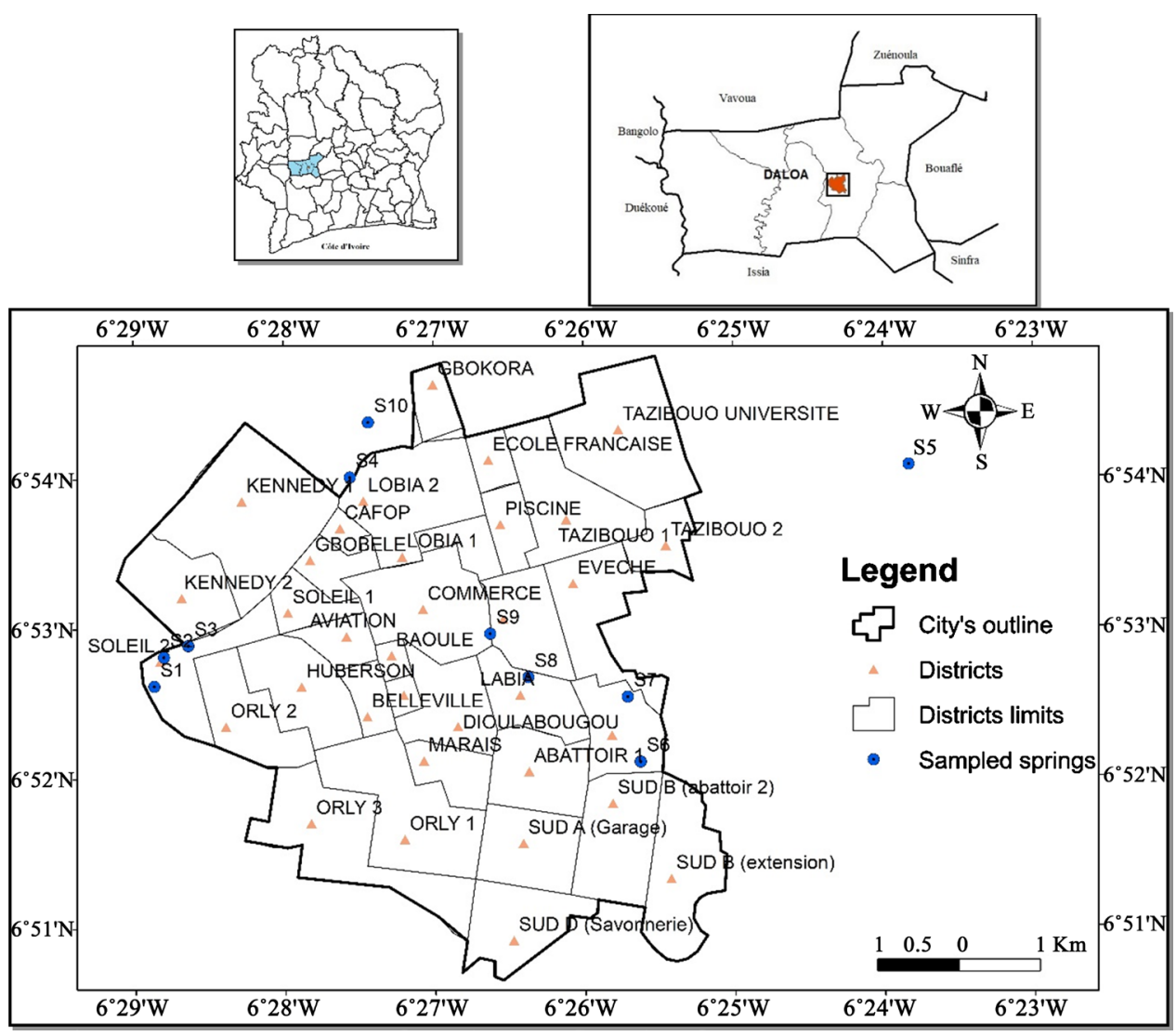

Figure 1. Location of the study area. 
(GCPH, 2014).

The climate of the region of Daloa is a transitional humid tropical climate characterized by a dry season from November to February and a rainy season from March to October, with two maxima, one in June and the other in September (Figure 2). As a result of vast land settlement movements in the region, the forest heritage has declined considerably (Brou, 2005). This has led to a steady decrease in local rainfall heights (Yao et al., 2012). According to the author, the average annual rainfall in the region rose to $1212.6 \mathrm{~mm}$ over the period 1973-2010, with a rainfall deficit of around $16 \%$.

\subsection{Materials}

\subsubsection{Study Data}

The data used in this study come from the results of physico-chemical analyses of water samples taken after a sampling campaign from ten (10) natural springs in the city of Daloa. They concern 14 parameters or variables: temperature $\left(\mathrm{T}^{\circ} \mathrm{C}\right)$, hydrogen potential $(\mathrm{pH})$, electrical conductivity $(\mathrm{EC})$, redox potential (Eh), saturation rate (SR), sodium $\left(\mathrm{Na}^{+}\right)$, nitrates $\left(\mathrm{NO}_{3}^{-}\right)$, sulphates $\left(\mathrm{SO}_{4}^{2-}\right)$, ammonium $\left(\mathrm{NH}_{4}^{+}\right)$, nitrites $\left(\mathrm{NO}_{2}^{-}\right)$, calcium $\left(\mathrm{Ca}^{2+}\right)$, chlorides $\left(\mathrm{Cl}^{-}\right)$, iron $\left(\mathrm{Fe}^{2+}\right)$ and manganese $\left(\mathrm{Mn}^{2+}\right)$.

\subsubsection{Data Processing Hardware}

The data processing hardware consists of the following software:

- Excel 2013 from Microsoft Office: it was used to organise and process the data;

- Statistica 7.1: It made it possible to carry out summary statistical analysis and principal component analysis (PCA) to highlight the characteristics and origin of water mineralization, respectively.

\subsection{Methods}

The results of the physico-chemical analyses of the natural spring water of the

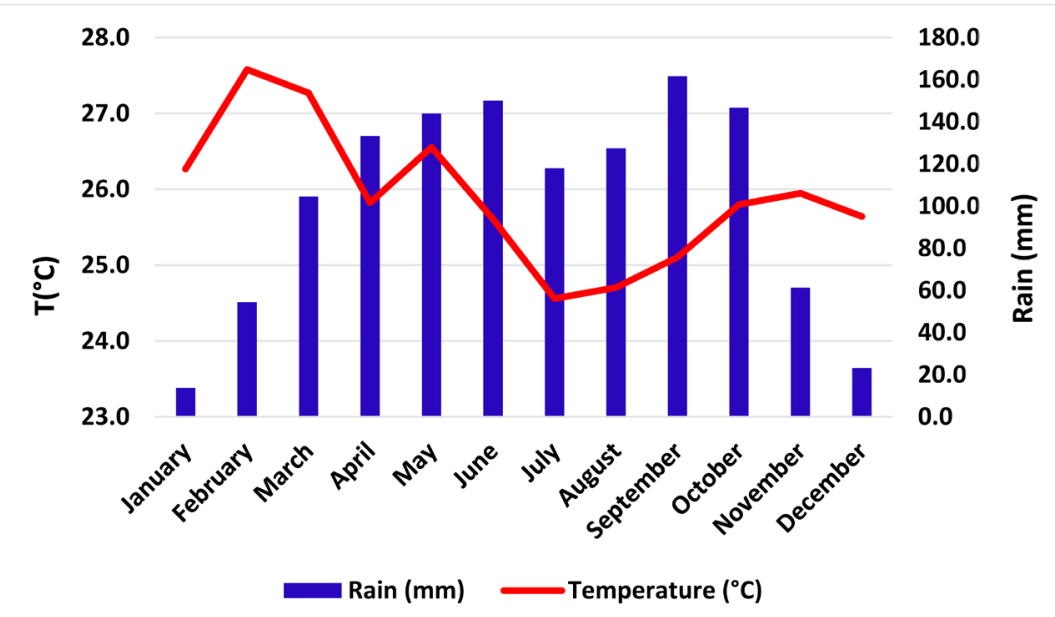

Figure 2. Ombrothermal diagram of the Daloa synoptic station over the period 1990-2015. 
city of Daloa have been organised and processed on Excel. Then, they were imported into the STATISTICA software to undergo statistical tests, including summary statistical analysis and finally, the normalized principal components analysis (NPCA).

\subsubsection{Summary Statistical Analysis}

It consists of comparing the extreme values (minimum and maximum), the central value (average) and the dispersion parameter (standard deviation) of the results of physico-chemical analyses with the drinking water guidelines for human consumption water (WHO, 2017).

\subsubsection{Normalized Principal Component Analysis (NPCA)}

It is a statistical method of description which makes it possible to synthesise and classify a large number of variables in order to extract the main factors which are at the origin of the simultaneous evolution of the variables and their reciprocal relations (Biémi, 1992). It is the subject of several applications (Parinet et al., 2004; Mahapatra et al., 2012; Garcia et al., 2017; Zeinalzadeh \& Rezaei, 2017; Zhang et al., 2020). The results are characterised by the following statistical elements: the correlation matrix, the eigenvalues of factors and the community circle. The NPCA of a study is only valid when the factorial designs studied provide more than $70 \%$ of the information sought (Biémi, 1992). Below this limit, it is considered that the study did not take into account a large amount of useful information that remains hidden.

\section{Results and Discussion}

\subsection{Results}

\subsubsection{Physico-Chemical Characteristics of Spring Water of the City of Daloa}

Table 1 represents a summary statistic of the results of the physico-chemical analyses of the water from natural spring in the city of Daloa in relation to the WHO guide values.

The $\mathrm{pH}$ values are between 4.81 and 5.39, with an average of $5.07 \pm 0.18$. The spring waters of the city of Daloa are acidic. The conductivity varies between 51.7 and $225 \mu \mathrm{S} / \mathrm{cm}$, with an average of $110.17 \pm 53.14 \mu \mathrm{S} / \mathrm{cm}$. These waters are on average very weakly mineralised with electrical conductivities lower than 100 $\mu \mathrm{S} / \mathrm{cm}$. Of the remaining $50 \%$, only the water from the spring of Fatima shows average mineralization $(225 \mu \mathrm{S} / \mathrm{cm})$.

The average concentrations of iron $(0.5 \pm 1.02 \mathrm{mg} / \mathrm{L})$ and manganese $(0.61 \pm$ $0.90 \mathrm{mg} / \mathrm{L}$ ) show that these two parameters are increasing in the spring waters of the city of Daloa.

\subsubsection{Correlation between Physico-Chemical Parameters}

There are strong correlations between some physico-chemical parameters (Table 2). Correlations are highly significant between $\mathrm{NO}_{3}^{-}, \mathrm{NO}_{2}^{-}$and $\mathrm{EC}(\mathrm{r}>$ 0.90). A significant positive correlation was observed between $\mathrm{Mn}^{2+}$ and $\mathrm{NH}_{4}^{+}$ 
$(\mathrm{r}=0.94)$. There is a strong negative correlation between $\mathrm{Ca}^{2+}$ and $\mathrm{SO}_{4}^{2-} \quad(\mathrm{r}=$ $-0.95)$ and, between Eh and $\mathrm{pH}(\mathrm{r}=-0.81)$. There are mean correlations between $\mathrm{Fe}^{2+}, \mathrm{Ca}^{2+}$ and $\mathrm{T}^{\circ} \mathrm{C}(\mathrm{r}=0.60)$; between $\mathrm{Cl}^{-}, \mathrm{Ca}^{2+}$ and $\mathrm{Na}^{+}(\mathrm{r}=0.61)$.

Table 1. Summary statistics of the physico-chemical parameters of spring waters.

\begin{tabular}{ccccccc}
\hline Studied parameters & Units & WHO Guidelines & Max. & Min. & Average & Standard deviation \\
\hline $\mathrm{T}^{\circ} \mathrm{C}$ & ${ }^{\circ} \mathrm{C}$ & $25-30$ & 29.50 & 27.70 & 28.59 & 0.52 \\
$\mathrm{pH}$ & & $6.5-8.5$ & 5.39 & 4.81 & 5.07 & 0.18 \\
$\mathrm{EC}$ & $\mu \mathrm{S} \cdot \mathrm{cm}^{-1}$ & $180-1000$ & 225.00 & 51.70 & 110.17 & 56.01 \\
$\mathrm{SR}$ & $\%$ & & 50.40 & 20.00 & 29.33 & 8.92 \\
$\mathrm{Eh}$ & $\mathrm{mV}$ & & 407.90 & 265.50 & 368.50 & 41.44 \\
$\mathrm{NO}_{3}^{-}$ & $\mathrm{mg} \cdot \mathrm{L}^{-1}$ & $\leq 50$ & 49.30 & 5.00 & 16.49 & 13.74 \\
$\mathrm{NO}_{2}^{-}$ & $\mathrm{mg} \cdot \mathrm{L}^{-1}$ & $\leq 3$ & 0.91 & 0.06 & 0.25 & 0.27 \\
$\mathrm{NH}_{4}^{+}$ & $\mathrm{mg} \cdot \mathrm{L}^{-1}$ & $\leq 1.5$ & 0.96 & 0.00 & 0.13 & 0.30 \\
$\mathrm{SO}_{4}^{2-}$ & $\mathrm{mg} \cdot \mathrm{L}^{-1}$ & $\leq 250$ & 5.00 & 0.00 & 0.60 & 1.58 \\
$\mathrm{Cl}^{-}$ & $\mathrm{mg} \cdot \mathrm{L}^{-1}$ & $\leq 250$ & 76.10 & 8.30 & 28.87 & 20.16 \\
$\mathrm{Fe}^{2+}$ & $\mathrm{mg} \cdot \mathrm{L}^{-1}$ & $\leq 0.3$ & 3.41 & 0.06 & 0.51 & 1.02 \\
$\mathrm{Mn}^{2+}$ & $\mathrm{mg} \cdot \mathrm{L}^{-1}$ & $\leq 0.2$ & 3.00 & 0.00 & 0.61 & 0.90 \\
$\mathrm{Ca}^{2+}$ & $\mathrm{mg} \cdot \mathrm{L}^{-1}$ & $\leq 200$ & 41.00 & 31.00 & 32.78 & 11.57 \\
$\mathrm{Na}^{+}$ & $\mathrm{mg} \cdot \mathrm{L}^{-1}$ & & 21.58 & 6.89 & 13.75 & 4.48 \\
\hline & & & & & \\
\hline
\end{tabular}

Table 2. Correlation coefficient matrix.

\begin{tabular}{|c|c|c|c|c|c|c|c|c|c|c|c|c|c|c|}
\hline & $\mathrm{T}^{\circ} \mathrm{C}$ & $\mathrm{pH}$ & EC & SR & Eh & $\mathrm{NO}_{3}^{-}$ & $\mathrm{NO}_{2}^{-}$ & $\mathrm{NH}_{4}^{+}$ & $\mathrm{SO}_{4}^{2-}$ & $\mathrm{Cl}^{-}$ & $\mathrm{Fe}^{2+}$ & $\mathrm{Ca}^{2+}$ & $\mathrm{Mn}^{2+}$ & $\mathrm{Na}^{+}$ \\
\hline $\mathrm{T}^{\circ} \mathrm{C}$ & 1.00 & & & & & & & & & & & & & \\
\hline $\mathrm{pH}$ & 0.00 & 1.00 & & & & & & & & & & & & \\
\hline EC & 0.11 & -0.41 & 1.00 & & & & & & & & & & & \\
\hline SR & -0.64 & -0.54 & 0.28 & 1.00 & & & & & & & & & & \\
\hline Eh & 0.01 & -0.81 & 0.02 & 0.45 & 1.00 & & & & & & & & & \\
\hline $\mathrm{NO}_{3}^{-}$ & 0.03 & -0.52 & 0.93 & 0.42 & 0.24 & 1.00 & & & & & & & & \\
\hline $\mathrm{NO}_{2}^{-}$ & 0.01 & -0.49 & 0.92 & 0.43 & 0.20 & 0.99 & 1.00 & & & & & & & \\
\hline $\mathrm{NH}_{4}^{+}$ & 0.06 & -0.24 & 0.26 & -0.05 & 0.17 & 0.11 & 0.12 & 1.00 & & & & & & \\
\hline $\mathrm{SO}_{4}^{2-}$ & -0.57 & 0.46 & -0.22 & -0.06 & -0.24 & -0.13 & -0.11 & -0.03 & 1.00 & & & & & \\
\hline $\mathrm{Cl}^{-}$ & 0.47 & 0.01 & 0.05 & -0.25 & 0.16 & -0.05 & -0.08 & 0.05 & -0.36 & 1.00 & & & & \\
\hline $\mathrm{Fe}^{2+}$ & 0.60 & 0.13 & -0.25 & -0.37 & 0.08 & -0.25 & -0.24 & -0.20 & -0.13 & 0.27 & 1.00 & & & \\
\hline $\mathrm{Ca}^{2+}$ & 0.60 & -0.51 & 0.30 & 0.11 & 0.32 & 0.25 & 0.26 & 0.01 & -0.95 & 0.43 & 0.24 & & & \\
\hline $\mathrm{Mn}^{2+}$ & -0.01 & -0.33 & 0.34 & 0.11 & 0.24 & 0.22 & 0.26 & 0.94 & 0.04 & -0.01 & -0.04 & 0.01 & 1.00 & \\
\hline $\mathrm{Na}^{+}$ & 0.44 & -0.08 & -0.16 & -0.07 & 0.25 & -0.04 & -0.05 & -0.57 & -0.51 & 0.61 & 0.29 & 0.61 & -0.59 & 1.00 \\
\hline
\end{tabular}




\subsubsection{Eigenvalues of Factors}

Table 3 presents the first three factors with their eigenvalue and the variance expressed.

The percentage of variances expressed is $30.38 \%$ for factor $1,26 \%$ for factor 2 and $14.95 \%$ for factor 3, i.e. $71.33 \%$. The first three factors account for more than $71 \%$ of the variance expressed, and therefore of the information sought. Thus, the mechanisms that control the chemical evolution of waters from natural springs of the city of Daloa are contained in these three factors (F1, F2 and F3).

\subsubsection{Variable Space Analysis}

The variable space analysis concerns the factor pairs $\mathrm{F} 1 \times \mathrm{F} 2$ and $\mathrm{F} 1 \times \mathrm{F} 3$.

Analysis of the variable space of the factorial plane F1 $\times$ F2 (Figure 3)

The factor $\mathrm{F} 1$ expresses $30.38 \%$ of the variance and is determined by the following parameters: $\mathrm{EC}, \mathrm{NO}_{3}^{-}, \mathrm{NO}_{2}^{-}, \mathrm{SR}$ and $\mathrm{Eh}$. The measurement of electrical conductivity (EC) makes it possible to quickly and accurately evaluate the overall mineralization of the water. Factor 1 is therefore considered to be the axis of

Table 3. Eigenvalues and percentage variance expressed.

\begin{tabular}{cccc}
\hline & Factor 1 & Factor 2 & Factor 3 \\
\hline Eigenvalues & 4.25 & 3.64 & 2.09 \\
Variance expressed (\%) & 30.38 & 25.99 & 14.95 \\
Cumulative eigenvalues & 4.25 & 7.89 & 9.99 \\
Cumulative variance (\%) & 30.38 & 56.37 & 71.32 \\
\hline
\end{tabular}

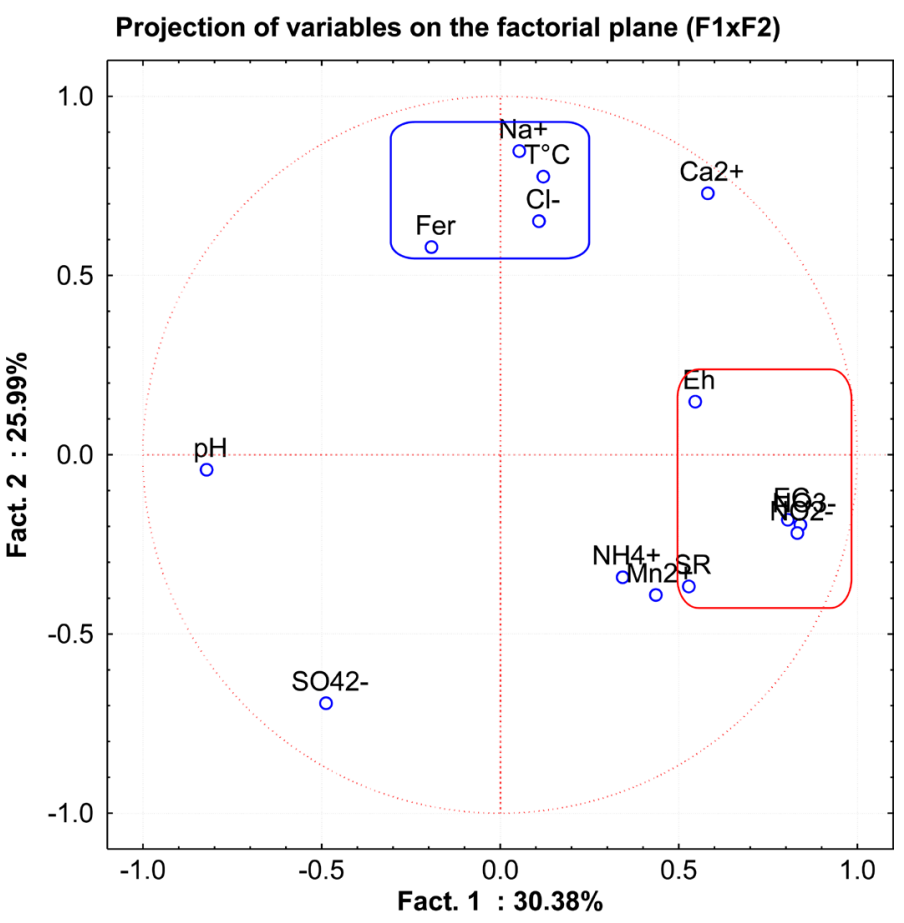

Figure 3. Variable space of the factorial plane F1 $\times$ F2. 
overall water mineralization. However, the grouping of nitrates $\left(\mathrm{NO}_{3}^{-}\right)$and nitrates $\left(\mathrm{NO}_{2}^{-}\right)$with electrical conductivity $(\mathrm{EC})$ reflects a mineralization linked to surface inputs of elements (anthropogenic pollution) in spring water. Moreover, the highly significant correlation between $\mathrm{NO}_{3}^{-}, \mathrm{NO}_{2}^{-}$and $\mathrm{EC}(\mathrm{r}>0.90)$ shows that the acquisition of mineralization is strongly influenced by anthropogenic pollution. In addition, the redox potential (Eh) and the dissolved oxygen saturation rate (SL) show that the presence of nitrate $\left(\mathrm{NO}_{3}^{-}\right)$and nitrite $\left(\mathrm{NO}_{2}^{-}\right)$ions is attributed to the oxidation-reduction phenomenon. Factor 1 therefore represents the axis of mineralization of spring water linked mainly to surface inputs of elements (anthropogenic pollution) and the oxidation-reduction phenomenon.

Factor 2 expresses $26 \%$ of the information sought and is determined by the following variables: $\mathrm{T}^{\circ} \mathrm{C}, \mathrm{Fe}^{2+}, \mathrm{Na}^{+}, \mathrm{Cl}^{-}$. Factor 2 is an axis of mineralization linked to the water-rock contact (mineralization-residence time). This phenomenon is very weakly expressed in the acquisition of the mineralization.

\section{Analysis of the variable space of the factorial plane F1 $\times$ F3 (Figure 4)}

The factorial plane $\mathrm{F} 1 \times \mathrm{F} 3$ represents $45.33 \%$ of the variance expressed and confirms the phenomena at the origin of the spring water mineralization observed after analysis of the space of variables of the factorial plane $\mathrm{F} 1 \times \mathrm{F} 2$ : mineralization linked to the surface input of elements (anthropogenic pollution), to the phenomenon of oxidation-reduction at water-rock contact (mineralization-residence time), very weakly expressed.

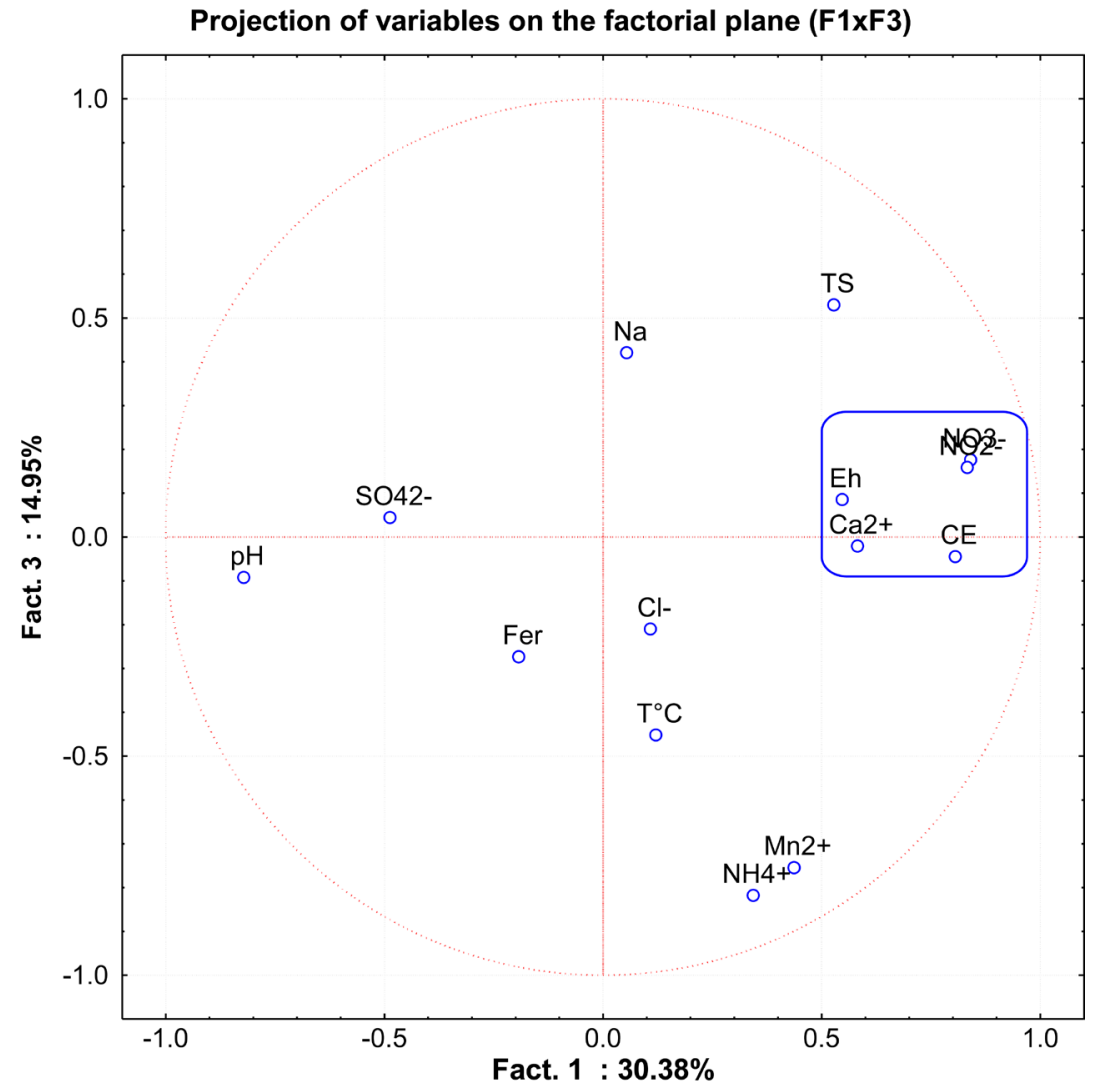

Figure 4. Variable space of the factorial plane F1 $\times$ F3 


\subsection{Discussion}

The study of the mode of acquisition of the mineralization of the water from natural springs in the city of Daloa was made from 14 physico-chemical parameters. The projection of these parameters in the variable space of the factorial plane $\mathrm{F} 1 \times \mathrm{F} 2$ gave the grouping of the following parameters: electrical conductivity (EC), nitrates $\left(\mathrm{NO}_{3}^{-}\right)$, nitrites $\left(\mathrm{NO}_{2}^{-}\right)$, redox potential (Eh) and dissolved oxygen saturation rate (SR) around the factor $\mathrm{F} 1$. The presence of $\mathrm{NO}_{3}^{-}$and $\mathrm{NO}_{2}^{-}$shows that the mineralisation of the spring water in the city of Daloa is linked both to the superficial inputs of elements (anthropogenic pollution) and to the oxidation-reduction phenomenon. This could be explained by the fact that these waters come from shallow aquifers. In fact, spring water is the natural emergence of groundwater that appears in a localised or diffuse manner on the surface of the ground. They are natural drainage areas or point outlets for ground water and can also be captured by wells or boreholes (De Marsily \& Besbes, 2017). Thus, due to their piezometric level close to the soil surface, these waters are exposed to anthropogenic pollution. The upward trend in nitrate concentrations in most groundwater has been noted by many authors (Graveline et al., 2009; Ahoussi et al., 2013; Eblin et al., 2019). The impact of anthropogenic activities on the quality of groundwater is a major global problem and is the subject of several studies (Bricha et al., 2007; Shahbazi \& Esmaeili-sari, 2009).

According to Ligban et al. (2009), the chemical signature of spring water, marked by low conductivities, is clearly similar to that of well water that collects the altered water table, and differs from that of borehole water that intercepts the fissured base. Analyses have shown that more than half (50\%) of the spring waters studied have electrical conductivities below $100 \mu \mathrm{S} / \mathrm{cm}$. The majority of these waters are very weakly mineralised. Other studies have concluded that the acquisition of groundwater mineralization is due to surface water inflow by infiltration (Alhassane et al., 2019). Moreover, the strong correlations between nitrates $\left(\mathrm{NO}_{3}^{-}\right)$, nitrites $\left(\mathrm{NO}_{2}^{-}\right)$and $\mathrm{EC}(\mathrm{r}>0.90)$ show a strong influence of this phenomenon in the acquisition of mineralisation. On the other hand, the very weak and sometimes negative correlations between some parameters of the overall water mineralization $\left(\mathrm{Ca}^{2+}, \mathrm{Na}^{+}, \mathrm{Cl}^{-}, \mathrm{SO}_{4}^{2-}\right.$, etc. $)$ and the electrical conductivity (EC) show a very weak influence of the mineralization-residence time (water-rock contact) in the acquisition mechanism of the mineralization. The low electrical conductivity values reveal that the water-rock contact time is not sufficient to allow the water to dissolve the rock and bring the mineral elements into solution. This corroborates the results of Ligban et al. (2009) which showed by calculation of saturation indices in relation to dolomite and calcite, and the use of the korjinski diagram that the low mineralization of the water from wells and natural springs in the square degree of Daloa reflects a short residence time.

\section{Conclusion}

The study of the mineralization of water from natural springs in the city of Daloa 
(West-central Côte d'Ivoire) revealed that this water is acidic and very weakly mineralized, with high iron and manganese contents. The $\mathrm{pH}$ values are between 4.81 and 5.39, while half of these waters have electrical conductivities below 100 $\mu \mathrm{S} / \mathrm{cm}$. Average iron and manganese contents are $0.5 \pm 1.02 \mathrm{mg} / \mathrm{L}$ and $0.61 \pm$ $0.90 \mathrm{mg} / \mathrm{L}$ respectively. The Normalized Principal Component Analysis (NPCA) shows that mineralization is governed by three phenomena: surface inputs of elements (anthropogenic pollution), the oxidation-reduction phenomenon and, the water-rock contact (mineralization-residence time). The highly significant correlation $(\mathrm{r}>0.90)$ between nitrates $\left(\mathrm{NO}_{3}^{-}\right)$, nitrites $\left(\mathrm{NO}_{2}^{-}\right)$and electrical conductivity (EC) reveals a strong influence of the superficial inputs of elements in the acquisition mechanism of the mineralization of these waters. It is therefore advisable to deepen research by monitoring the parameters of mineral and organic pollution in order to prevent a health risk linked to the consumption of this water.

\section{Conflicts of Interest}

The authors declare no conflicts of interest regarding the publication of this paper.

\section{References}

Ahoussi, K. E., Koffi, Y. B., Kouassi, A. M., Soro, G., \& Biemi, J. (2013). Hydrochemical and Microbiological Study of Spring Water in the Mountainous West of Côte d'Ivoire: The Case of the Village of Mangouin-Yrongouin (Sub-Prefecture of Biankouman). Journal of Applied Biosciences, 63, 4703-4719. https://doi.org/10.4314/jab.v63i1.87245

Alhassane, I., Sani, M. A. B., Issoufou, S., Souleymane, S. I. M., \& Boureima, O. (2019). Hydrogeochemical Characterization of the Aquifers of the Timia Basin (Aïr Massif, Northern Niger). European Scientific Journal, 15, 301-3016.

https://doi.org/10.19044/esj.2019.v15n30p301

Awomon, D. F., Coulibaly, M., Niamke, G. M., \& Santos, D. S. (2018). The Problem of Drinking Water Supply and the Development of Water-Borne Diseases in the ORLY Extension Neighbourhoods in the City of Daloa (Côte d'Ivoire). Space, Territories, Societies and Health Magazine, 1, 91-108.

Biémi, J. (1992). Contribution to the Geological, Hydrogeological and Remote Sensing Study of the Subsahelian Watersheds of the Precambrian Basement of West Africa: Hydrostructural, Hydrodynamic, Hydrochemical and Isotopic Analysis of Discontinuous Trench Aquifers and Granitic Area of Upper Marahoué (479 p.). PhD Thesis in Natural Sciences, Abidjan: University of Cocody-Abidjan (Côte d'Ivoire).

Boubakar, H. A. (2011). Shallow and Deep Aquifers and Urban Pollution in Africa: The Case of the Urban Community of Niamey (Niger) (249 p.). PhD Thesis, Niamey: Abdou Moumouni University of Niamey, Niger.

Bricha, S., Ounine, K., Oulkheir, S., El Haloui, N., \& Attarassi, B. (2007). Study of the Physicochemical and Bacteriological Quality of the M'nasra Water Table (Morocco). Afrique Science, 3, 391-404.

Brou, Y. T. (2005). Climate, Socio-Economic Changes and Landscapes in Côte d'Ivoire. Summary of Scientific Activities (212 p.). Habilitation to Conduct Research, Lille: University of Science and Technology of Lille, France.

Chaouki, I., Mouhir, L., Fekhaoui, M., El Abidi, A., Bellaouchou, A., \& El Morhit, M. (2015). Application of the Principal Component Analysis (PCA) for the Assessment of 
the Quality of Industrial Wastewater from Salam Gas-Skhirat. Journal of Materials and Environmental Science, 6, 455-464.

De Marsily, G., \& Besbes, M. (2017). Groundwater. Responsibility \& Environment, 86, 25-30. https://doi.org/10.3917/re1.086.0025

Eblin, S. G., Konan, K. S., Mangoua, O. M. J., Nedeff, V., Sandu, A. V., Barsan, N., \& Sandu, I. (2019). Nitrate Pollution of Groundwater Based on GIS in the City of Daloa, West-Central Cote d'Ivoire. Revista de Chimie (Bucharest), 70, 2578-2583. https://doi.org/10.37358/RC.19.7.7384

Eblin, S. G., Soro, G., Sombo, A. P., Aka, N., Kambiré, O., \& Soro, N. (2014). Hydrochemistry of Groundwater in the Region of Adiaké (Southeast Coastal of Côte d'Ivoire). Larhyss Journal, 17, 193-214.

Garcia, C. A. B., Garcia, H. L., Mendonca, M. C. S., Silva, A. F., Alves, J. P. H., Costa, S. S. L., Araujo, G. O., \& Silva, I. S. (2017). Assessment of Water Quality Using Principal Component Analysis: A Case Study of the Açude da Macela-Sergipe-Brazil. In XVIth World Water Congress. México: International Water Resources Association (IWRA).

GCPH (General Census of Population and Housing) (2014). Directory of Localities: Region of Haut-Sassandra Region (38 p.).

Graveline, N., Rinaudo, J.-D., Loubier, S., \& Segger, V. (2009). The Evolution of Agricultural Groundwater Pollution: An Approach Based on the Coupling of Economic and Biophysical Models. Rural Economy, 310, 22-39.

https://doi.org/10.4000/economierurale.2136

Jain, P., Sharma, J. D., Sohu, D., \& Sharma, P. (2005). Chemical Analysis of Drinking Water of Villages of Sanganer Tehsil, Jaipur District. International Journal of Environmental Science and Technology, 2, 373-379.

Ligban, R., Gone, D. L., Kamagate, B., Saley, M. B., \& Biemi, J. (2009). Hydrogeochemical Processes and Origin of Natural Springs in the Square Degree of Daloa. International Journal of Biological and Chemical Science, 3, 38-47.

Mahapatra, S. S., Sahu, M., Patel, R. K., \& Panda, B. N. (2012). Prediction of Water Quality Using Principal Component Analysis. Water Quality, Exposure and Health, 4, 93-104. https://doi.org/10.1007/s12403-012-0068-9

Parinet, B., Lhote, A., \& Legube, B. (2004). Principal Component Analysis: An Appropriate Tool for Water Quality Evaluation and Management-Application to a Tropical Lake System. Ecological Modelling, 178, 295-311. https://doi.org/10.1016/j.ecolmodel.2004.03.007

Shahbazi, A., \& Esmaeili-sari, A. (2009). Groundwater Quality Assessment in North of Iran: A Case Study of the Mazandaran Province. World Applied Sciences Journal, 5, 92-97.

Soro, G., Soro, T. D., Fossou, N. M. R., Adjiri, O. A., \& Soro, N. (2019). Application of Multivariate Statistical Methods to the Hydrochemical Study of Groundwater in the Lakes Region (Central Côte d'Ivoire). International Journal of Biological and Chemical Sciences, 13, 1870-1889. https://doi.org/10.4314/ijbcs.v13i3.54

WHO (2017). Guidelines for Drinking-Water Quality (4th ed., 442 p). Geneva: World Health Organization.

Yao, A. B., Goula, B. T. A., Kouadio, Z. A., Kouakou, K. E., Kané, A., \& Sambou, S. (2012). Analysis of Climate Variability and Quantification of Water Resources in the Humid Tropical Area: The Case of the Lobo Watershed in West-Central of Côte d'Ivoire. Ivorian Journal of Science and Technology, 19, 136-157.

Zeinalzadeh, K., \& Rezaei, L. (2017). Determining Spatial and Temporal Changes of Surface Water Quality Using Principal Component Analysis. Journal of Hydrology: Regional Studies, 13, 1-10. https://doi.org/10.1016/j.ejrh.2017.07.002 
Zhang, X., Zhang, Y., Zhang, Q., Liu, P., Guo R., Jin, S., Liu, J., Chen, L., Ma, Z., \& Liu, Y. (2020). Evaluation and Analysis of Water Quality of Marine Aquaculture Area. International Journal of Environmental Research and Public Health, 17, 1-15.

https://doi.org/10.3390/ijerph17041446 